\title{
Pancasila and Religious Harmony
}

\author{
Prof. Abdurrahman Mas'ud, $\mathrm{PhD}$ \\ Universitas Islam Negeri Walisongo Semarang, Indonesia
}

\{abdurrahman@walisongo.ac.id\}

\begin{abstract}
Being as a nation that exhibits pluralism, Indonesia has a potential for conflict. The fundamental causes of conflict between one region and another are similar. Some are triggered by economic inequality, political feuds, or religious contestation. The various conflicts that have occurred in the last few years show a decline in societal value and national crisis. The founding fathers were brilliantly able to agree on a choice on the basis of the state in accordance with the national character, namely Pancasila. Apparently, Pancasila is a common vision needs to be further pursued. Pancasila is a guideline for state administration. Pancasila, as the ideology of the nation, needs to be preserved not only for the integrity of the nation, but also for real benefits in maintaining the integrity of each one Pancasila is the foundation for constructing a multicultural life with Indonesian characteristics.
\end{abstract}

Keywords: Pancasila; Religious Harmony

\section{Introduction}

As the basis for the state and the ideology of the nation, Pancasila must be used as the basis for the formulation of policies and practices of the state and nationhood. Therefore, the practice of Pancasila is not only limited to the state apparatus, but also society. In order to strengthen religious harmony, Pancasila must be used as a guiding star (Leitstar), both for policy making and strengthening the culture of tolerance among religious communities.

Strengthening the harmony of the people based on Pancasila values is prominent, so that all practices of national life are synchronized with the foundation of our country. This is important considering that there has been a current intolerance in the body of religious people, due to the rise of radicalism and sectarianism in religion. Structurally, religious radicalism challenges the established foundation of the Indonesian state. The radical group then questions various consensuses on the establishment of the nation, including Pancasila, as well as the form of the Republic of Indonesia, the 1945 Constitution and the principle of pluralism which is implemented at the jargon of Unity in Diversity (Bhinneka Tunggal Ika).

In the cultural sphere, this radical group also provokes hate speech, disbelief, and acts of terrorism. This group continues to spread various hate speeches against people of different religions, as well as people of different beliefs. It is because such community doesn't define Indonesia as part of the Islamic State (Daulah Islamiyyah) while they intend to construct Islam as a basis state of the nation. Due to not being an Islamic nation, Indonesia is claimed as a war zone (dar al-harb). Therefore, various propaganda, violence and legitimate terrorism as is customary in a state of war are spreading out. 
Various policies and efforts have been made by the Government, especially by the Indonesian Ministry of Religious Affairs. Mainstreaming of religious harmony is constructed through the formation of the Forum for Religious Harmony (FKUB) in all provinces, districts and cities, and coordinated by the Central Ministry of Religious Affairs and Ministry of Home Affairs. FKUB has a strategic role as a forum for unity, friendship, communication, reconciliation and consolidation among interfaith leaders in maintaining harmony. In order to measure the development of harmony in society, the Ministry of Religious Affairs has also compiled an Index of Religious Harmony which is published annually.

In this article, the writer will re-base efforts to strengthen religious harmony based on the basis of Pancasila as the state and ideology of the nation. It is pivotal to be done considering that the Government of President Joko Widodo has reinforced Pancasila ideology both at the policy and institutional levels. The strengthening of Pancasila has been conducted by President Joko Widodo from the first period of his administration (2014-2019) to the second period (2019-2024), which includes;

a. Issuance of Presidential Decree No. 24 of 2016 concerning Pancasila Day on June 1. This Presidential Decree establishes June 1, 1945 as the Birthday of Pancasila, considering that on that day, the idea of Pancasila was first conveyed by the initiator of Pancasila, namely Ir. Sukarno. Through this Presidential Decree, President Jokowi has returned the correct preparation of Panacsila's history. In the Dictum Considering letter E in the Presidential Decree, it is stated that 1 June 1945, 22 June 1945 (the Nine Committee Meeting which produced the Jakarta Charter) and 18 August 1945 (the PPKI Session which ratified the final formulation of Pancasila) constitute an integral part of the birth process, formulation and ratification of the final of Pancasila formula.

b. Establishment of a Presidential Work Unit for the Development of Pancasila Ideology (UKP-PIP) through Presidential Regulation No. 54 of 2017 concerning UKP-PIP. This Presidential Work Unit is tasked with compiling the Guidelines for the Development of the Pancasila Ideology (GHBPIP), as well as providing input to the President regarding the development of the Pancasila ideology.

c. Establishment of the Pancasila Ideology Development Agency (BPIP) through Presidential Regulation No. 7 of 2018 concerning BPIP. This non-ministerial state institution is a continuation of UKP-PIP.

d. The dissolution of Islamic organizations that oppose Pancasila, namely Hizbut Tahrir Indonesia (HTI) through Government Regulation in Lieu of Law (Perppu) No. 2 of 2017 concerning Community Organizations (Ormas). This Perppu has been enacted as Law no. 16 of 2017 concerning Ormas. Through this Perppu, the Joko Widodo administration has dissolved the organization that carries the Khilafah ideology, which explicitly opposes Pancasila and the Republic of Indonesia.

Based on these various regulations, Pancasila is now being strengthened, both by the Government and by the parliament, one of which is through the preparation of a Draft Law on the Development of Pancasila Ideology which is being drafted by the Indonesian Parliament and supported by the Indonesian People's Consultative Assembly. Thus, the preparation of an effort to strengthen religious harmony based on Pancasila has become the spirit of the times that is coming upon this nation.

\section{Results and Discussions}

\subsection{Pancasila Ideology of Tolerance}


Since its beginning, Pancasila was constructed as the basis for the state and nation's ideology which integrates with harmony. Sukarno on June 1, 1945 proposed the idea of Pancasila as a meeting point between the two political and religious views that developed at the First Session of the Investigative Body for Preparatory Efforts for Independence (BPUPK) which took place on 29 May-1 June 1945. The two views refer to the nationalistic view, which advocates nationality as the basic principle of the state. Faced with Islamist views, which propose Islam as the basis of the state, Sukarno then delivered a speech on the last day of the BPUPK's First Session, and succeeded in proposing thoughts that could unite the two views.[1] In this regard, Sukarno offered several principles.

First, proposing nationality as the first principle of the foundation of the state which is defined as Pancasila. What is meant by nationality is a principle that places Indonesia as a "one for all" country. Not a country for one particular group or group. This principle criticizes the concept of an Islamic State which will place Muslims as the main citizens, marginalizing people of other religions who will become minorities. Because from the start, the people wanted to establish a state for all, the first principle that must be the basis for the state is nationality.

Second, proposing democracy as the third principle of the Pancasila idea. Democracy in question is a democratic mechanism in parliament, where all groups can channel their aspirations through the deliberation method to reach consensus. Sukarno specifically proposed this principle to Islamic groups as a guarantee of the opportunity to channel Islamic aspirations through parliament. Thus, even though the established state is a nation-state, within that country, Muslims can still fight for their aspirations through democratic procedures. Of course, the democratic mechanism itself will ensure whether these aspirations can be legalized into legal regulations or not. This means that all these processes are returned to the spirit of deliberation for consensus.[2]

Third, proposing the belief in the one and only God (Ketuhanan Yang Maha Esa) as the fifth principle of the Pancasila idea on June 1. After proposing nationalism (the first precept), internationalism (the second principle), deliberation to reach consensus (the third principle) and social welfare (the fourth principle), Sukarno then proposed the belief in the one and only God Divinity as the fifth principle. Therefore, Sukarno stated:

"The fifth principle should be: Developing an independent Indonesia by fearing God Almighty. Divine Principle! Not only is the Indonesian nation godly, but each Indonesian should believe in God, his own God. Christians worship God according to the instructions of Isa al-Masih, Moslems belief is to the instructions of the Prophet Muhammad SAW, Buddhists carry out their worship according to the books that exist in him. The state of Indonesia should be a country where everyone can worship God freely. All people should be culturally devoted, that is, with no "religious egoism". And the State of Indonesia should be a country that believes in God!"[3]

Furthermore, Sukarno added:

"Let us practice it, practice religion, both Islam and Christianity, in a civilized manner. What is the civilized way? It is respect for one another. ... Let us, in this Free Indonesia which we compile, accordingly, state: that the fifth principle of our country is a cultural divinity, a deity with noble character, a deity that respects one another. My heart will celebrate, if you agree that the Free Indonesia State is based on the principle of the belief of only one God!"[3]

From Sukarno's point of view above, the divinity that is used as a principle in Pancasila is divinity that is practiced tolerantly by giving freedom to every religious adherent to believe according to their respective religions. This is a tolerant divine and religious principle, which 
teaches harmony between religious communities. By proposing Divinity as one of the precepts in Pancasila, Pancasila then becomes the basic idea of the state which is accepted by all BPUPK Session participants. This happens because divinity becomes a common sentence between Islamic and nationalist groups. For the Islamic group, the divine idea of Pancasila then presents the most fundamental value of religion, namely divinity, which in Islam is called tauhid. On the other hand, the nationalist group, the divine idea of Pancasila represents an inclusive, tolerant, religious viewpoint and does not represent a particular religious doctrine.[4] Because even though Pancasila is based on divinity, it does not make the Pancasila State a religious state. Divinity is the substantial value of all religions representing the aspirations of all religions.

On June 1, 1945, Sukarno placed divinity as the fifth precept. It defines as the root for the precepts. At the Nine Committee Meeting on June 221945 chaired by Sukarno, divinity was raised as the first precept and meaning as the source. On that day, divinity was then imbued with the sentence "with the obligation to carry out Islamic law for its adherents". This is what is called the Jakarta Charter version of the Pancasila formula. However, the historical process then proved that this exclusive concept of divinity was then revised by the founders of the nation. On the morning of August 18, 1945 before the PPKI Session, Bung Hatta discussed with Islamic groups, namely Kiai Wahid Hasyim, Ki Bagus Hadikusumo, Teuku Hasan and Kasman Singodimedjo to remove the "seven words of sharia" from Pancasila. These Islamic leaders agreed that the editorial of the first principle of Pancasila became the belief of one and only God. For the consecutive time, the founders of the nation showed their siding in national unity, rather than the aspirations of one people. Therefore, the basic values of Pancasila are fundamentally seen as a definitive formulation process. Pancasila is the basis of the state and national ideology which advocates unity, tolerance, harmony and care for plurality.

\subsection{The Rejection of Pancasila}

Although from the beginning it has been the nation's ideology that cares for diversity, Pancasila is not free from challenges. One of these challenges was developed by Islamic radical groups that reject Pancasila in the name of Islam. This rejection of Pancasila in the name of Islam has indeed become a trend in the post-Reformation era. Several survey institutions have captured this trend. The Indonesian Survey Circle Survey (LSI) Denny JA in 2018, for example, found a 9\% decrease in support for Pancasila. At the same time, Muslim support for the idea of NKRI Bersyariah increased by $10 \%$. This trend of increasing and decreasing support occurred for 13 years, from 2005 to 2018. The question is, why does the support for NKRI Bersyariah appear higher than the support for Pancasila?

The idea of NKRI Sharia was developed by the Imam of the Islamic Defenders Front (FPI), Habib Rizieq Shihab. What is meant by this idea is the total application of Islamic law within the framework of the form of the Republic of Indonesia and the ideology of Pancasila. It is different from the Islamic State system or Khilafah Islamiyyah, because NKRI sharia does not replace the national state system and the nation's ideology. It only strengthens the application of sharia, not as a constitution (dustur) but as a law (qanun). Within the NKRI Sharia, the application of sharia is not limited to the field of worship and mu'amalah (social relations), but also criminal laws (jinayah). The application in this criminal area will totalize the enforcement of sharia. Currently, jinayah is not implemented in Indonesia, which makes the application of sharia considered incomplete.

For the sake of establishing this NKRI Sharia, Pancasila needs to be revised by reviving Piagam Jakarta which is a basic formulation of the state that was agreed upon by the founders 
of the state on June 22, 1945. In the charter, Pancasila has the affix of the syar'i sentence in the first principle, namely Divinity by Implementing Islamic Sharia for its adherents. For Habib Rizieq, this formula is considered to be more ideal than the valid Pancasila formula, in which the "seven words of Islamic law" have been deleted.

Thus, Pancasila and NKRI Bersyariah are actually a contestation between the formulations of the pure Pancasila versus the Pancasila of the Jakarta Charter. The question is, is it true that pure Pancasila is against Islamic sharia? Whereas at the National Alim Ulama Conference held by Nahdlatul Ulama (NU) in Situbondo 1983, it was stated that Pancasila was a reflection of monotheism and sharia. The first precept reflects the values of monotheism. Meanwhile, the principles under it, including humanity, unity, democracy and justice reflect the values of Islamic sharia. Thus according to NU, practicing Pancasila is the same as practicing tauhid and sharia.[5]

The same data was reported by the Alvara Research Center survey in 2017 which found the rejection of some Muslims against Pancasila. Among professionals there are $15.5 \%$ rejecters of Pancasila, $16.8 \%$ among students, $18.6 \%$ students and $19.4 \%$ of the State Civil Apparatus (ASN). This support is still a minority when compared to the supporters of Pancasila who are still in the range of $80 \%$. However, this $15-19 \%$ rejection should not be underestimated, because it will become a "thorn in the flesh" of the nation's life.

The people against Pancasila naturally chose the basis of the nation as an Islamic state. Thus, the population of $15-19 \%$ of Muslims agrees that the basis of our country is Islam, not Pancasila. This illustrates the understanding among the ummah that still clashes between Islam and Pancasila. As stipulated by NU above, Pancasila is a reflection of the fundamental values of Islam, namely monotheism and sharia. Although Pancasila is not the basis of an Islamic state, it contains Islamic religious values. A similar decree was also made by Muhammadiyah, which held its 47th Congress in Makassar, on August 3-7 2015 declaring Indonesia as dar al'ahdi wa al-syahadah which is a state of agreement and testimony. What is meant by the agreement is the consensus of the founders of the nation, in which the Muhammadiyah figure, $\mathrm{Ki}$ Bagus Hadikusumo, is a member of the Indonesian Independence Business Investigation Board (BPUPK) and the Preparatory Committee for Indonesian Independence (PPKI). The consensus on the basis of the state was then given the name Pancasila. The consensus further relates to the form of a national state, a modern constitution and a democratic political system. These various consensuses must be obeyed by Muslims, because in the agreement, there are pledges that must be kept.

Based on the views and acceptance of the two largest Islamic social organizations, there is actually no reason for Muslims to reject Pancasila. It is not like a banned organization such as Hizbut Tahrir Indonesia (HTI) which denounces Pancasila for two reasons. First, Pancasila is considered to adhere to religious pluralism. When the basis of this state protects all religions in Indonesia, HTI judges Pancasila has developed religious pluralism. What Pancasila has developed is not religious leveling, but rather the protection of its existence and citizens' rights to religion. The realm of Pancasila is only an "external protector", without entering the theological dimension of religions. Second, because according to HTI, Pancasila has embraced ideological pluralism because within the foundation of this country there are ideologies that are contrary to Islam. The ideology in question is nationalism, democracy and socialism. HTI's view is also incorrect because the ideologies in Pancasila do not contradict Islam.[6]

With the existence of the Islamic radical group's rejection of Pancasila, the basis of this country is facing challenges from groups that are indeed against diversity. This is a challenge in itself considering that this group is quite effective in propagating its ideas in society, especially among educated people who are unfamiliar with religious knowledge. 


\subsection{Religious Harmony Policy}

In maintaining inter-religious tolerance in Indonesia, the Indonesian government has actually issued various aimed and strengthened legal products. It starts from policies that specifically regulate inter-religious harmony, as well as establishing a foundation for religious rights as a basis for the practice of tolerance. This regulatory principle is normatively based on two basic values in the life of the nation. First, Pancasila and Bhinneka Tunggal Ika and the relationship between religion and state which tolerates each other are the second.

The first value, which is the basis and principle of national unity, describes the objective conditions and nature of the Indonesian nation that is able to unite in plurality. This is the objective condition of the Indonesian people, because it is a cultural continuity from the civilization of the archipelago to modern national life. Whereas in the past, the Nusantara nation was able to maintain religious plurality through the unity of truth, then in modern Indonesia, this unity should not be something difficult. Therefore, all efforts to divide the nation through religious conflicts have become something historical, because they violate the cultural nature of the Indonesian people.

This achievement of inter-religious harmony has become a mainstream fact of religious life in Indonesia. The national survey of religious harmony by the Ministry of Religion of the Republic of Indonesia in 2012 showed that the national harmony index reached 3.67 (scale 15 ), which means it is quite harmonious. That there are cases of intolerance at several points do need to be addressed, but the national picture appears satisfying. This is confirmed by a similar harmony survey in 2015 which obtained a national average of 75.36, which means reaching the high harmony category. The high harmony in question is the working of the harmony dimensions, namely tolerance $(71.26 \%)$, equality $(75.66 \%)$ and cooperation between people $(80.44 \%)$. Unfortunately, the number of Religious Harmony that rose in 2015 fell in 2019, with a national score of 73.83.[7] This shows the decline in the quality of religious harmony given the strength of religious sentiment used, for example in political practice. However, even though it has decreased, this still shows that the outline of our religious life is in a harmonious condition.

Meanwhile, the second value of harmony management departs from the principle of the relationship between religion and the state which adheres to twin tolerance based on the values of Pancasila. On the other hand, the state tolerates religion by not interfering with the religious rights of citizens, at the same time, facilitating religious life. Efforts to maintain intercommunity harmony are part of the process of facilitating this religious life. On the other hand, religion also tolerates the state by not formalizing the state so as to form a monolithic religious state, which ultimately conflicts with the pluralistic nature of the nation.[8]

The principle of this twin tolerance has been carried out by the state, although it still has many weaknesses here and there. In the constitutional realm, the state respects the right to religion in the form of freedom of religion and belief, and protects these rights from the threat of discrimination. Meanwhile, in the realm of harmony care, the state has actually produced many laws on inter-religious harmony. If it turns out that there is still disturbance of harmony, both in the form of religious intolerance, discrimination in the name of religion, to blasphemy; then the problem is caused by a complex problem.

In addition to formulating rules on harmony, constitutionally our country has established the protection of the right to religion for citizens. This right is placed in religious rights, as well as human rights (HAM) in general. This shows that Indonesia is a humanitarian country that protects its citizens to practice religion freely and solemnly. 
Article 28E paragraph 1 of the 1945 Constitution states, Everyone has the right to embrace a religion and worship according to their religion. Paragraph 2 also states that, Everyone has the right to freedom of belief, to express thoughts and attitudes in accordance with their conscience. Meanwhile, Article 28I paragraph 2 states, Everyone is free from discriminatory treatment on any basis and has the right to receive protection against such discriminatory treatment.

From these articles, it can be seen that the principles of human rights are closely related to the right to religion and to give birth to protection against discrimination, especially in the name of religion. This means that the state realizes itself as an authority that is not authorized to intervene in the form of obstruction of the right to religion, because it prominently human rights. On the other hand, the state positions itself as a protector against discriminatory actions against religious groups, if that group or adherents experience discrimination based on their religion.

This human rights article was later strengthened by the article on religious freedom. Article 29 paragraph (2) states: The state guarantees the freedom of each resident to embrace his or her own religion and worship according to that religion and belief. This was later clarified by the Elucidation of Article 1 of the Law. No. 1/ PNPS / 1965 by mentioning 6 religions adhered to by Indonesians, namely Islam, Christianity, Catholicism, Hinduism, Buddhism and Confucianism. These six religions receive guarantees, assistance and protection in accordance with Article 29 paragraph (2). This does not mean that other religions, for example: Judaism, Zoroaster, Shinto, Taoism, etc. are prohibited in Indonesia. They get full guarantee and are left as they are as long as their people do not break the law.

In addition, the decision of the Constitutional Court (MK) on the request for a judicial review of Law no. 1 / PNPS / 1965 issued in 2010. This request was filed by a group of people considering that the law is considered discriminatory because it only recognizes the 6 religions above. Upon this request, the Constitutional Court stated: Considering whereas the Petitioners' argument which states that the Blasphemy Prevention Law is discriminatory because it only limits recognition of six religions, according to the Constitutional Court, it is not true, because the Law does not limit recognition or protection to only six religions, however recognizes all religions practiced by the Indonesian people. Thus, this Constitutional Court decision clears up the misunderstanding of the petitioner and society at large, that it seems that there are only six religions in Indonesia. On the contrary, based on Law no. 1/ PNPS / 1965, the state clearly emphasizes that all religions are protected, although not all of them are served administratively.

In this case, the state does not have the capacity to recognize and evaluate the theology of religions, so that there are not only six religions in Indonesia. The state also has a definition and criteria for religion. For example, that this religion is a universal religion that has also developed in other countries; has come and developed in Indonesia for decades; it has theology, prophets, and holy books, the number of people in the thousands, rites and places of worship. This religious criterion is different from local beliefs which are the spiritual treasures of Indonesian society. Including a belief as a religion clearly develops an anthropological definition of religion, formulated by anthropological scientists, not religionists.

Unfortunately, the management of inter-religious harmony is still facing challenges. The Indonesian constitution has mandated the right to religion for every citizen, joint ministerial regulation making, to the establishment of the Forum for Inter-Religious Harmony (FKUB); but here and there, problems still arise. Since this republic was founded, at least various interreligious regulations have been established in order to manage harmony, including: 
a. Presidential Decree No. 1 of 1965 concerning the Prevention of Abuse and / or Blasphemy of Religion.

b. Joint Decree of the Minister of Religion and the Minister of Home Affairs No. 01 / BER / mdg-mag / 1969 concerning the Implementation of Government Apparatus Duties in Ensuring Order and Smoothness of the Implementation of Religious Development and Worship by Adherents.

c. Law no. 5 of 1969 concerning Statements of Various Presidential Decrees and Presidential Regulations as Laws.

d. Letter of the Minister of Home Affairs No. 264 / KWT / DT-PUM / DV / V / 1975 regarding the Use of a Home as a Church.

e. Instruction of the Minister of Religion No. 4 of 1978 concerning Policies Regarding Belief Sects.

f. Joint Decree of the Minister of Religion and the Minister of Home Affairs No. 1 of 1979 concerning Procedures for Implementing Religious Broadcasting and Foreign Assistance to Religious Institutions in Indonesia.

g. Decree of the Minister of Religion No. 35 of 1980 concerning the Forum for InterReligious Deliberation.

h. Instruction of the Minister of Religion of the Republic of Indonesia No. 3 of 1981 concerning the Implementation of Fostering Harmony of Religious People in the Regions in Relation to the Establishment of Inter-Religious Deliberative Forums.

i. Circular of the Minister of Religion No. MA/432/1981 concerning Organizing Religious Holidays.

j. Presidential Instructions in connection with the Circular of the Minister of Religion No. MA / 432/1981.

k. Decree of the Minister of Religion of the Republic of Indonesia No. 84 of 1996 concerning Implementation Guidelines for the Overcoming of Religious Harmony Harmoniousness.

1. Presidential Decree No. 6 of 2000 concerning the Revocation of Presidential Instruction No. 14 of 1967 concerning Religion, Beliefs and Customs of China.

m. Joint Regulation of the Minister of Religion and the Minister of Home Affairs No. 9 and 8 of 2006 concerning Guidelines for Implementing the Duties of Regional Heads / Deputy Regional Heads in Maintaining Religious Harmony, Empowering FKUB and Establishing Houses of Worship.

n. Letter of the Minister of Religion No. MA / 12/2006 concerning Explanation of Marital Status According to Confucian Religion and Confucian Religion Education.

o. Minister of Home Affairs Circular No. 450/2576 / SJ regarding the Formation of FKUB and the FKUB Advisory Board.

p. Joint Ministerial Regulation (Minister of Religion and Minister of Home Affairs) No. 9 and 8 of 2006 concerning the Construction of Houses of Worship, etc.

So far, the legal basis for religious life is centered on Law No.1 / PNPS / 1965. Therefore, more regulations are needed to strengthen along with the increasingly complex religious problems that threaten harmony. This is understood as the mandate of reform in the field of religious life as contained in Article 29 of the 1945 Constitution and in the idea of the 1998 MPR-RI Special Session. Two mandates were stipulated. First is the protection of religious communities. Second is to strengthening inter-community networks, in order to strengthen religious harmony. These two things were later strengthened in Law no. 25/2001 concerning the National Development Program (Propenas) 2000-2004. This law states the need for 
drafting a Law on Religious Harmony with the aim of strengthening the basics of internal and inter-religious harmony, as well as for the development of social harmony and national unity.

It is in this context that in 2003, the state through the Ministry of Religious Affairs formulated the Draft Bill on Religious Harmony (KUB). Although the draft was formulated through the support of religious communities, such as the Indonesian Ulama Council (MUI), the process of ratification encountered obstacles and challenges from several groups, especially religious minorities. According to these circles, the KUB Bill is considered to contain a majority-religious bias which allows discrimination against minorities. In 2009, the House of Representatives (DPR) took over the efforts to draft the KUB Bill to become the DPR Initiative Draft. The draft KUB Bill was also drafted by the DPR until the 2011 KUB Bill Draft was formulated. Although the government has developed a draft, the same fate as before, the DPR version of the bill has also received rejection from many circles. Until the end of the 2009-2014 DPR RI service periods, the KUB Bill has not been passed.

In order to respond towards this issue, the Ministry of Religious Affairs triggered the need for a Bill on the Protection of Religious People (PUB). This is a recommendation from the dialogue of the Ministry of Religious Affairs with various religious leaders. The basic idea is to formulate a pro-religious minority law, because the previous bill, namely the KUB Bill, was considered majority-biased. So it is different from the attitude towards the RUU KUB, the minority groups support this PUB Bill (Litbang Kemenag, 2014: 49). Based on a survey conducted by the Research and Development Agency and Education and Training Center, Center for Research and Development of Religious Life, the Ministry of Religious Affairs of the Republic of Indonesia in 2014, it is illustrated that $91.12 \%$ of religious leaders in Indonesia agree with the PUB Bill, which deals with nine issues that are often hot spots for religious harmony. The nine problems are; religious broadcasting, construction of houses of worship, religious education, blasphemy, religious holidays, interfaith marriages, foreign aid, adoption of children and funerals.

In this case, the PUB draft bill is directed at least to resolve problems that revolve around three things. First, it is the issue relating to blasphemy. Good Law no. 1 / PNPS / 1965 as well as Article 156a of the Criminal Code on Blasphemy of Religion were tested against the Constitutional Court. However, the Constitutional Court rejected this judicial review, because the Blasphemy Law was deemed necessary to maintain the purity of religious teachings and prevent conflicts between people caused by the blasphemy. Thus, the Blasphemy Law does not contradict the constitution. It's just that the Constitutional Court's decision in 2010 also recommended a revision of the Law in order to clarify the definition of blasphemy, so that the rules are clear and not abused by certain parties. The PUB draft bill wants to implement this MK recommendation.

In this context, Western countries have indeed revoked the Blasphemy Law because it is considered to have harmed democracy and human rights. The UK lifted it in 2008, while other countries are shifting the blasphemy law to territory prohibiting hate speech. In the West the Blasphemy Law was abolished because for them, what is considered as blasphemy is part of freedom of thought and expression. So rather than regulating blasphemy, Western society is more interested in regulating blasphemy of religious adherents. This means that what is prohibited is not freedom of thought about religion, but behavior that creates hatred and enmity between religious adherents. This is different from the context in Indonesia which still maintains the blasphemy regulation, because religion must be protected from deviant views. Only, indeed, the government needs to clarify which actions are categorized as blasphemy, which are merely differences in interpretation of religious texts or heresy. 
Second, the regulation of religions outside the six major religions becomes the issue. This was triggered by the will of small religions such as Sikh, Baha'i, Tao, as well as local beliefs such as Kaharingan and Sunda Wiwitan to be recognized and served by the state. The request to be recognized by the state doesn't appear relatively correct, because the Indonesian constitution is not in a position to recognize and limit the existence of religion in Indonesia. Therefore, the government needs to be wise in making this arrangement so as not to cause misunderstanding among religious communities.

Third, the problem of building houses of worship which has been regulated by PBM No. 9 and 8 of 2006. This is indeed a classic problem of religious communities in Indonesia which has not been maximally managed by the government. It often becomes a point of conflict in the regions, based on conflict between the majority and minority relations. In an area with a certain religious majority, it is difficult for minorities to build houses of worship.[9]

\subsection{Harmony Based on Pancasila}

Based on the data on regulations and religious issues above, it is necessary to strengthen religious harmony based on Pancasila. This is necessary to strengthen efforts to mainstream religious harmony that have occurred. Strengthening religious harmony needs to begin from the values of Pancasila since the beginning the ideology of this nation has indeed become a meeting point that reconciles various political and religious views in our nation. The strategic position of Pancasila as the basis for strengthening religious harmony is due to the nature of Pancasila as a moderate ideology that idealizes, one of which is religious understanding. Thus, Pancasila truthfully contains the principles of religious moderation.

The principle of religious moderation contained in Pancasila lies in the conception of divinity which is practiced through the values of humanity, nationality, democracy and social justice. This is the hallmark of the synthetic Pancasila paradigm. This means that even though it contains five principles containing five ideas and values, Pancasila is a separate idea formed by the synthesis of these five ideas. This synthesis refers to the synthesis between the idea of divinity and humanity, nationality, democracy and social justice. Through this synthesis, the divinity in Pancasila, and in fact is also the basic principle of divine values in all religions; always be humane, nationalistic, democratic and socially just.[10]

Therefore, through Pancasila, it is emphasized that divine values are always humane, nationalistic, democratic and socially just. Divinity is human, because the main value of divine teaching is the glorification of human dignity. In Islam, this is reflected in the five principles (ushul al-khams) the main objective of sharia (maqashid al-syari'ah) in the form of protection of religion (hifdz al-din), protection of life (hifdz al-nafs), protection of reason (hifdz al-'aql), protection of offspring (hifdz al-nasl) and protection of property (hifdz al-maal). The protection of basic human rights is the main objective of Islamic law enforcement. Thus, it is appropriate for Pancasila to place divinity and humanity in bonds of mutually reinforcing values.

The same is true for the synthesis between divinity and nationality. Nationality does not only refer to the idea of a nation-state, but the principle of national unity that lies within it. This happens because in nationality, unity is the main value in order to build a nation. Therefore, what is meant by a nation is the unity of society among various ethnic, racial, linguistic, religious and ideological diversity united by the same practice of life. The principle of unity is also emphasized by the teachings of God, for example reflected in QS al-Maidah: 48, where Allah SWT calls out the importance of respecting differences in the midst of 
diversity which is sunnatullah. Thus, the principle of unity in religious teachings is God's command. This reflects the unity between divine and national principles in Pancasila.

From this perspective, it can be understood that strengthening of religious harmony can not only be built on the basis of religious tradition, but also with the conceptions and values of Pancasila. This happens because in Pancasila, divinity becomes a source of value that illuminates its values.

\section{References}

[1] A. B. Kusuma, Lahirnya Undang-Undang Dasar 1945. Depok: Badan Penerbitan Fakultas Hukum Universitas Indonesia, 2016.

[2] A. Basarah, Bung Karno, Islam dan Pancasila. Jakarta: Penerbit Konstitusi Press, 2017.

[3] Sukarno, Lahirnya Pancasila, dalam Pancasila Sukarno. Jakarta: Badan Pendidikan dan Pelatihan Pusat PDI Perjuangan, 2019.

[4] A. S. Ali, Negara Pancasila, Jalan Kemaslahatan Berbangsa. Jakarta: LP3ES, 2009.

[5] S. H. M. Hasan and A. M. Mulkhan, Latar Belakang Ummat Islam Menerima Pancasila sebagai Asas Tunggal (Sebuah Kajian Informatif Pandangan NUMuhammadiyah). Yogyakarta: Aquarius.

[6] Puslitbang Kehidupan Keagamaan, Pandangan Hizbut Tahrir Indonesia terhadap Pancasila. Jakarta: Puslitbang Kehidupan Keagamaan, Balitbang dan Diklat Kementerian Agama RI, 2012.

[7] H. Prabowo, "Daftar Skor Indeks Kerukunan Beragama versi Kemenag 2019," tirto.id, 2019. [Online]. Available: www.tirto.id/daftar-skor-indeks-kerukunan-beragama-versikemenag-2019-engH.

[8] Y. Latif, Negara Paripurna, Historisitas, Rasionalitas dan Aktualitas Pancasila. Jakarta: Gramedia Pustaka Utama, 2011.

[9] "Laporan Utama, Perlindungan Umat Beragama," Majalah Silaturahim Litbang Diklat, Edition Negara Melayani Agama-agama, 2015.

[10] E. Darmaputera, Pancasila, Identitas dan Modernitas, Tinjauan Etis dan Budaya. Jakarta, 1997. 